\title{
The mediating role of export-oriented Japanese foreign direct investment
}

\section{in China*}

\author{
Chen-Chen Yong ${ }^{1}$, Siew-Yong Yew ${ }^{2}$, Pei-Lee Teh ${ }^{3}$ \\ (1. Institute of China Studies, University of Malaya, Kuala Lumpur 50603, Malaysia; \\ 2. Faculty of Economics and Administration, University of Malaya, Kuala Lumpur 50603, Malaysia; \\ 3. Faculty of Management, Multimedia University, Cyberjaya 63100, Malaysia)
}

\begin{abstract}
Since the early 1990s, China has become the largest destination of Japanese foreign direct investment (FDI). Observing this trend, the authors analyzed whether Japanese FDI did promote exports from China to the rest of the world, and more importantly, whether this is a strategy adopted by Japanese multinationals to penetrate not only the Chinese market but also the global market. This analysis takes into account not only the direct effects of FDI on exports, but also the indirect effects, by examining the mediating role of export oriented Japanese FDI in China from 1998 to 2007 through panel analysis. The study contributes to the conceptual framework of indirect relationship among the macroeconomic variables, FDI and exports provides some insights into the strategy of export oriented Japanese FDI in creating a win-win platform for Japan and China.
\end{abstract}

Key words: foreign direct investment; exports; panel analysis; indirect effects

\section{Introduction}

China's economic growth has been driven by foreign direct investment (FDI) and exports. Since the early 1990s, part of the growth has resulted from aggressive volumes of Japanese FDI (Japan External Trade Organization). The bulk of the Japanese FDI inflow into China is in the manufacturing sector as shown in Table 1.

These Japanese firms have set up production bases in China to reduce production costs and avoid trade barriers in order to create a win-win platform for both Japan and China, as Japanese affiliates in China can sell their goods in China, and China can export their goods to Japan or other countries. From Fig. 1, Japanese manufacturing affiliates' sales in China, exports to Japan and exports to the rest of the world have shown an increasing trend from 2002 to 2007. Since 2002, the exports of Japanese manufacturing affiliates in China to Japan surpassed that to the rest of the world. Despite the Asian financial crisis in 1997, sales within China of Japanese affiliates in China far exceed exports to Japan and to other countries, thus exhibiting the growing size of the Chinese market. This may be due partly to the economic slow-down in the US economy since 2000. The export-led growth model seems to have slacked off for China due to decreasing external demand. At the same time,

\footnotetext{
* Acknowledgement: This paper was presented at the All China Economics (ACE) International Conference, Hong Kong, December 14-16, 2009. This work is supported in part by University of Malaya.

Chen-Chen Yong, Ph.D., senior lecturer, Institute of China Studies, University of Malaya; research fields: international economics, international trade.

Siew-Yong Yew, Ph.D., senior lecturer, Faculty of Economics and Administration, University of Malaya; research fields: international economics, foreign direct investment, economic integration.

Pei-Lee Teh, Master, lecturer, Faculty of Management, Multimedia University; research fields: total quality management and managerial economics.
} 
China has boosted their domestic market through domestic consumption and FDI. This dichotomy has raised the question of whether China will become the production base for Japan to penetrate not only the world market but mainly the growing domestic Chinese market.

Table 1 Japan's FDI in China

\begin{tabular}{lllllr}
\hline Year & $\begin{array}{l}\text { Manufacturing } \\
\text { FDI (US\$ million) }\end{array}$ & $\begin{array}{l}\text { Share of manufacturing } \\
\text { FDI in total FDI from } \\
\text { Japan to China (\%) }\end{array}$ & $\begin{array}{l}\text { Non-manufacturing } \\
\text { FDI (US\$ million) }\end{array}$ & $\begin{array}{l}\text { Share of } \\
\text { non-manufacturing } \\
\text { FDI in total FDI from } \\
\text { Japan to China (\%) }\end{array}$ & $\begin{array}{l}\text { Total FDI from Japan } \\
\text { to China (US\$ million) }\end{array}$ \\
\hline 1998 & 792.90 & 75.35 & 242.23 & 23.02 & $1,052.31$ \\
1999 & 547.95 & 72.71 & 174.25 & 23.12 & 753.65 \\
2000 & 793.77 & 76.78 & 237.66 & 22.99 & $1,033.84$ \\
2001 & $1,321.97$ & 88.33 & 172.29 & 11.51 & $1,496.71$ \\
2002 & $1,365.06$ & 79.53 & 234.99 & 13.69 & $1,716.48$ \\
2003 & $2,392.56$ & 79.06 & 608.99 & 19.87 & $3,065.21$ \\
2004 & $3,758.17$ & 82.84 & 586.77 & 12.93 & $4,536.77$ \\
2005 & $5,112.52$ & 77.58 & $1,477.31$ & 22.42 & $6,589.84$ \\
2006 & $4,875.32$ & 79.06 & $1,291.49$ & 20.94 & $6,166.81$ \\
2007 & $4,181.66$ & 67.43 & $2,018.68$ & 32.55 & $6,201.19$ \\
\hline
\end{tabular}

Data source: UNCTAD.

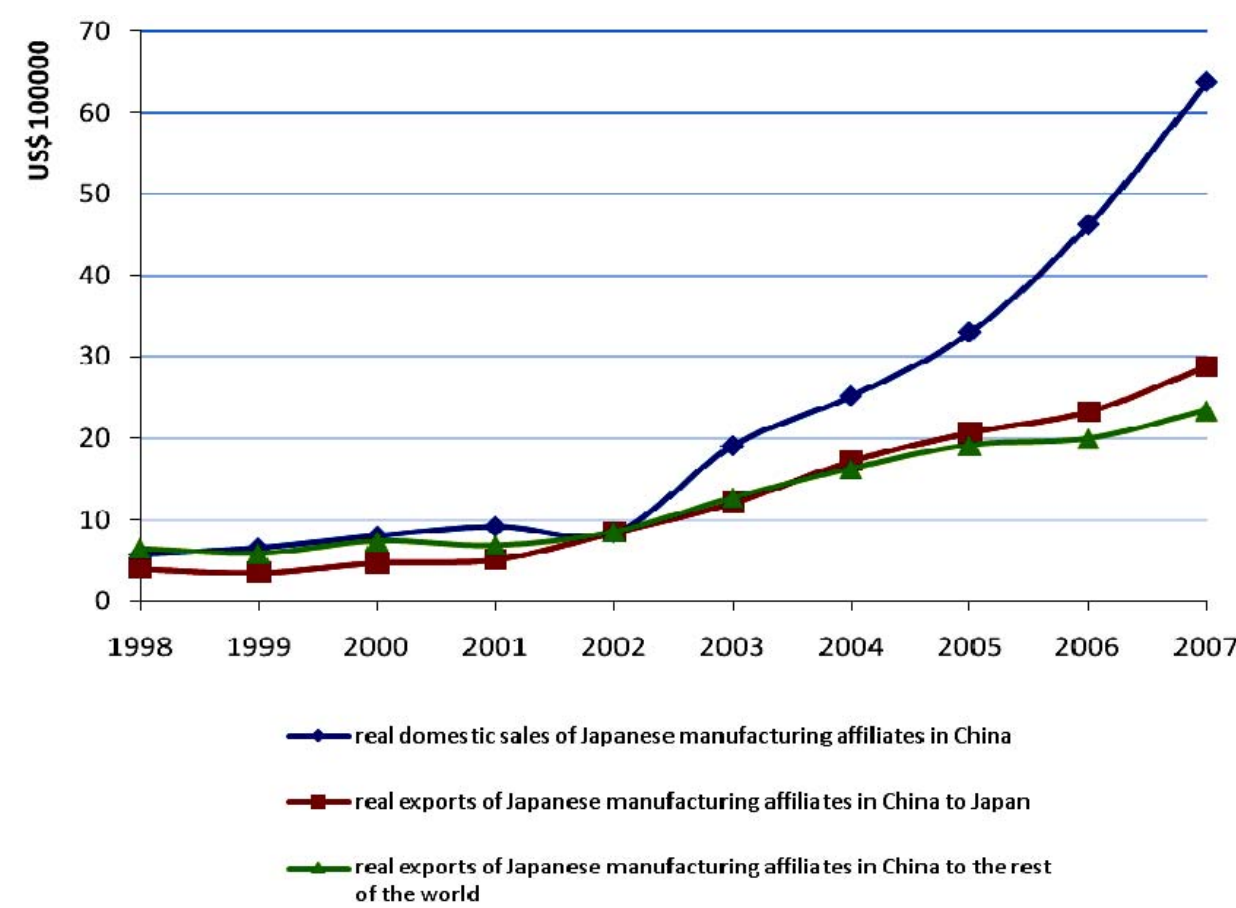

Fig. 1 Sales of Japanese manufacturing affiliates in China and exports to Japan and to the rest of the world (1998-2007)

Data source: Authors' calculation based on the data obtained from Ministry of Economy, Trade and Industry, Japan (METI) which include food and tobacco, textiles, chemicals, metals, industry machinery, electrical machinery, transportation equipment and others.

The examination of causal relationships between FDI and exports is also vital for development policy. If there is a causality from FDI to exports, FDI will act as a conduit for export expansion, vice versa. This implies 
that increasing Japanese FDI in China will increase the exports of Japanese affiliates in China and the total exports of China. Consequently, will Japanese FDI in China hollow out the domestic industry in Japan?

There is a growing body of literature (XING \& ZHAO, 2008; YU \& ZHAO, 2008; CHEN \& WANG, 2007; LIU, WANG \& WEI, 2001; SUN, 2001; ZHANG \& Felmingham, 2001; ZHANG \& SONG, 2000) on the relationships of FDI and exports for China's exports demand. However, the linkages (i.e., unidirectional or bidirectional relationships) between FDI and exports in China's exports demand model are relatively understudied. LIU, et al (2001) and ZHANG and Felmingham (2001) studied the causal relationships between FDI and export based on multivariate and bivariate exports demand model of China respectively. They have, however, excluded the standard explanatory variables (i.e., income and price) in the examination of exports demand behavior. LIU, et al (2001) highlighted that although multivariate Granger causality tests has been conducted to examine the causal relationships among three variables (i.e., FDI, exports and imports) based on vector autoregressive (VAR) analysis, the results should be interpreted with caution. This is because Granger causality does not imply that one variable is the effect or the result of another, but refers to the precedence of one variable over the others (LIU, et al., 2001, p. 199). Thus, the linkages between FDI and exports will become more complex when an additional explanatory variable is added into the analysis. As such, this study attempts to examine the indirect relationships among the macroeconomics variables, FDI and exports by using the multiple regression analysis proposed by Baron and Kenny (1986) and Kenny, Kashy and Bolger (1998).

Besides that, the linkages between FDI and exports are complex. The determinants of both FDI (e.g., KANG \& Lee, 2007; Cassidy \& Callaghan, 2006; Blonigen, 2005; SUN, TONG \& YU, 2002) and exports (e.g., Kumar, 2009; Kiyota \& Urata, 2008; XING \& ZHAO, 2008; Vukšić, 2005; Camarero \& Tamarit, 2004; LIU, et al., 2001; SUN, 2001; ZHANG \& Felmingham, 2001; ZHANG \& SONG, 2000) are overlapping. In addition, previous studies have examined the direct relationships between FDI and exports (WONG \& TANG, 2009; Apergis, Lyroudi \& Vamvakidis, 2008; Dritsaki, Dritsaki \& Adamopoulos, 2004). The indirect effects among the macroeconomic variables, FDI and exports have been widely discussed theoretically but the empirical evidence is rather scarce. Therefore, the authors aim to contribute to the conceptual framework and empirical evidence of the indirect relationships among the macroeconomic variables, FDI and exports also provide some insights into the new strategy of exports which incorporates the mediating role of FDI. In particular, the authors apply panel analysis to examine the exports performance of Japanese manufacturing affiliates in China from 1998 to 2007.

This paper is structured as follows: The development of the conceptual framework is described in section 2, which is followed by a description of the methodology in section 3. The empirical analyses are discussed in section 4. Finally, conclusions are presented in section 5.

\section{Conceptual framework}

We have examined the indirect relationships among macroeconomic variables and exports by taking into account of the mediating role of export-oriented Japanese FDI in China. Mediation refers to the effect of an explanatory variable on a dependent variable transmitted through a mediator variable (Edward \& Lambert, 2007, p. 1). According to Hair, Black, Babin, Anderson and Tatham (2006) and Mackinnon, Lockwood, Hoffman, West and Sheets (2002), mediation refers to an indirect effect. The terms mediated effects and indirect effects have a relatively long tradition in social sciences (WANG, TONG, CHEN \& Kim, 2009; Branstetter, 2006; Swenson, 2004; Baron \& Kenny, 1986), and are used interchangeably. The meaning of mediation can be illustrated in Fig. 2 
and Fig. 3 as models for depicting a causal chain.

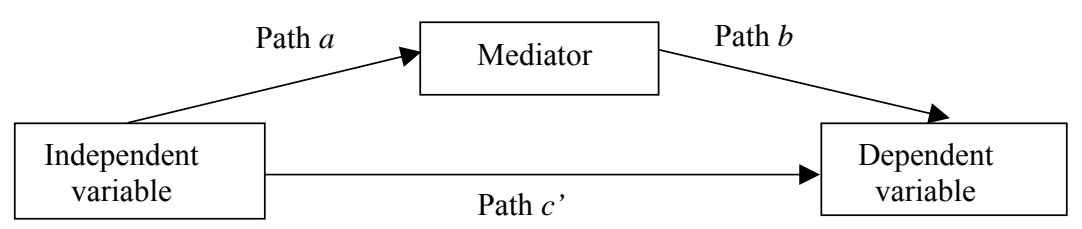

Fig. 2 Causal chain involved in mediation

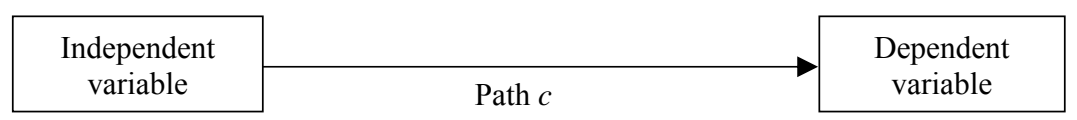

Fig. 3 Causal chain without mediator

Past studies had analyzed the relationships between FDI and exports based on the model illustrated in Fig. 3. In addition, in previous studies, the exports demand and FDI models used the same determinants (i.e., income and price). Past trade theories had evolved from traditional Heckscher-Ohlin framework (H-O) to Markusen (1984) and Helpman (1984) and had emphasized the importance of FDI in international trade. The central proposition of $\mathrm{H}-\mathrm{O}$ framework assumed that the international mobility of factors of production could equalize factor process across countries. In the conventional view of the Mundell (1957) model, the relationships between international trade and factor movements are substitutes rather than compliments. Markusen (1983) provides explanations of complementary effects between factors movements and international trade. The new trade theories in Markusen (1984) and Helpman (1984) suggest that efficiency-seeking FDI may have mainly complementary relationships with trade, and market-seeking FDI will have substituting relationships with trade. FDI will endogenously improve the efficiency of host countries indirectly through the diffusion of new technologies and management practices. This is expected to bring about dynamic changes in the comparative advantage of a country resulting from FDI, and in turn change the structure of international trade.

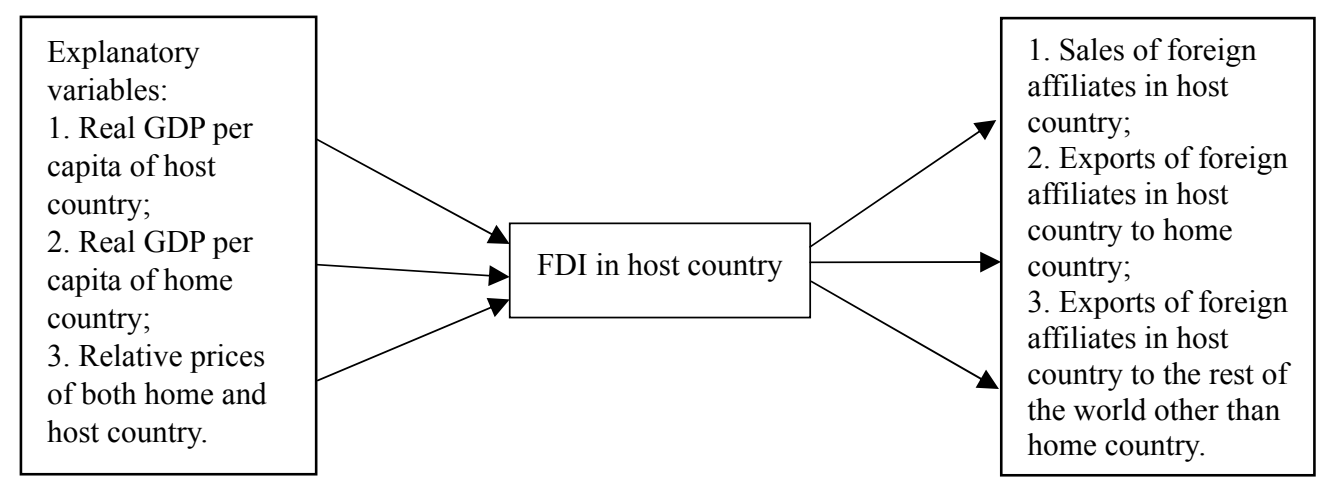

Fig. 4 Conceptual framework

The potential mediators should be identified on theoretical grounds (Holmbeck, 1997) and can be changed (Mackinnon, Krull \& Lockwood, 2000). The standard demand theory of exports is a function of income and relative prices and the new trade theory has incorporated the importance of FDI in determining the export growth of a country. However, there is no clear guide on variable selection in predicting FDI inflow into a country based on theoretical frameworks. Hermes and Lensink (2003) explained that the explanatory variables included for FDI models depend very much on the aim of the study and the insight and belief of the researcher. Therefore, FDI is chosen as the mediator variable rather than exports. Hence, the conceptual framework of this study is developed 
based on the bilateral exports demand model which includes the standard explanatory variables of income and relative prices to examine the indirect effects relationship among the macroeconomic variables, FDI and exports (see Fig. 4). The conceptual framework is developed to examine the Japanese FDI strategy in penetrating not only the market of China but also the world market.

\section{Methodology}

Three models are developed based on the proposed conceptual framework to assess whether Japan is able to penetrate both the China and world markets and also whether Japanese FDI in China is hollowing out domestic firms in Japan. They are as follows:

$$
\begin{aligned}
& X_{c i t}=\beta_{o i t}+c^{\prime} Z_{1 i t}+b F D I_{i t}+e_{i t} \\
& X_{j i t}=\beta_{o i t}+c^{\prime} Z_{2 i t}+b F D I_{i t}+e_{i t} \\
& X_{r i t}=\beta_{0 i t}+c^{\prime} Z_{3 i t}+b F D I_{i t}+e_{i t}
\end{aligned}
$$

where,

$X_{c}$ is the real domestic sales of Japanese manufacturing affiliates in China;

$X_{j}$ is the real exports of Japanese manufacturing affiliates in China to Japan;

$X_{r}$ is the real exports of Japanese manufacturing affiliates in China to the rest of the world;

$Z_{1}$ comprises the explanatory variables of PGDPC, PGDPJ and $P$, where PGDPC is the manufacturing industry's real domestic product per capita of China, $P G D P J$ is the manufacturing industry's real domestic product per capita of Japan, $P$ is the relative consumer price index of the respective manufacturing industry in China and Japan multiplied with the exchange rate between Japan and China;

$Z_{2}$ has the same set of explanatory variables as $Z_{1}$;

$Z_{3}$ comprises the explanatory variables of $P G D P W, P G D P C$ and $P$, where $P G D P W$ is the world manufacturing industry's real domestic products per capita, $P G D P C$ is the manufacturing industry's real domestic product per capita of China, $P$ is the relative consumer price index of the respective manufacturing industry in China and the world consumer price index multiple with the exchange rate between US and China;

FDI is the Japanese manufacturing FDI in China;

es' are the error terms;

$\beta_{0} s^{\prime}$ are the intercept terms;

$b$ and $c^{\prime}$ are the coefficients of the explanatory variables;

$i$ is the manufacturing industry which includes food and tobacco, textiles, chemicals, metals, industry machinery, electrical machinery, transportation equipment and others.

All variables are in the form of natural logarithms based on the constant price of $2005=100$ and in U.S. dollars. Data of the real domestic sales of Japanese manufacturing affiliates in China, the real exports of Japanese manufacturing affiliates in China to Japan and to the rest of the world are collected from METI. FDI data is obtained from UNCTAD and other data are from Euromonitor International to ensure consistency. Due mainly to data availability, the analysis period is confined to 1998 to 2007. In addition, it is interesting to examine the short run dynamics that traces the post Asian financial crisis time-path of exports. Therefore, this study uses panel analysis.

Due to the small sample size of observation, the mediation analysis is conducted by using the multiple regression analysis suggested by Baron and Kenny (1986) and Kenny, et al (1998). Four regressions are estimated 
for each model as follows:

$$
\begin{gathered}
X_{i t}=\beta_{\text {oit }}+c Z_{i t}+e_{0 i t} \text {, shown by path } c \text { in Fig. } 3 \\
F D I_{i t}=\beta_{1 i t}+a Z_{i t}+e_{1 i t} \text {, shown by path } a \text { in Fig. } 2 \\
X_{i t}=\beta_{2 i t}+b F D I_{i t}+e_{2 i t} \text {, shown by path } b \text { in Fig. } 2 \\
X_{i t}=\beta_{3 i t}+c^{\prime} Z_{1 i t}+b F D I_{i t}+e_{3 i t} \text {, shown by path } c^{\prime} \text { in Fig. } 2
\end{gathered}
$$

A variable acts as a mediator when $c, a$ and $b$ in equation (4) to equation (7) are significant. Then, a significance test for the indirect effect of the explanatory variable on dependent variable through the mediator (FDI) can be obtained by hand-calculable statistical z-test proposed by Baron and Kenny (1986) as follows:

$$
\frac{a b}{\sqrt{b^{2} S_{a}{ }^{2}+a^{2} S_{b}{ }^{2}+S_{a}{ }^{2} S_{b}{ }^{2}}}
$$

where,

$a$ is the coefficient of the explanatory variable to mediator;

$b$ is the coefficient of the mediator to dependent variable;

$S_{a}$ is the standard error of $a$;

$S_{b}$ is the standard error of $b$;

$\sqrt{b^{2} S_{a}{ }^{2}+a^{2} S_{b}{ }^{2}+S_{a}{ }^{2} S_{b}{ }^{2}}$ is the standard error of indirect effect estimate.

Table 2 summarizes the characteristics of the different mediators.

Table 2 Type of mediator

\begin{tabular}{|l|l|l|}
\hline \multicolumn{1}{|c|}{ Full mediator } & \multicolumn{1}{|c|}{ Partial mediator } & \multicolumn{1}{c|}{ Not a mediator } \\
\hline $\begin{array}{l}\text { Require the full effect of independent } \\
\text { variable on dependent variable be } \\
\text { carried by the mediator. }\end{array}$ & $\begin{array}{l}\text { The explanatory variables may have their own } \\
\text { direct effects on dependent variable that } \\
\text { independent of the mediator. }\end{array}$ & $\begin{array}{l}\text { The effect of explanatory variable on } \\
\text { dependent variable is not caused by the } \\
\text { mediator. }\end{array}$ \\
\hline$b$ is significant in equation (7). & $b$ is significant in equation (7). & $\begin{array}{l}b \text { could be significant or insignificant in } \\
\text { equation (7). }\end{array}$ \\
\hline$c$ is significant in equation (4). & $c$ is significant in equation (4). & $c$ is significant in equation (4). \\
\hline$c^{\prime}$ is not significant in equation (7). & $\begin{array}{l}c^{\prime} \text { is significant in equation (7) but the } \\
\text { coefficient of c' is smaller in equation (7) as } \\
\text { compared to the coefficient of c in equation (4). }\end{array}$ & $\begin{array}{l}c^{\prime} \text { is significant in equation (7) and the } \\
\text { coefficient of } c \text { and } c \text { ' in equation (4) and } \\
\text { equation (7) respectively, are the same. }\end{array}$ \\
\hline
\end{tabular}

Note: The definition of mediation is from Ryu, West and Sousa (2009).

\section{Results}

Three models are examined in this study. Multiple regression analysis (equation (3) to equation (8)) for each model has been estimated to examine the mediating role of Japanese export-oriented FDI in China. The mediating roles of Japanese FDI in penetrating China's market are revealed in the results for Model 1 in equation (1) as summarized in Table 3 and Table 4. As in Table 3, the estimation for equation (4) has a low adjusted $R^{2}$ as compared to equation (4) in Table 4. Therefore, Model 1 has been re-estimated by dropping the insignificant variable of $P G D P J$. Thus, the determinants of Japanese manufacturing goods demand in China are the China's real GDP per capita, relative prices and Japanese FDI (see Table 4). The results in Table 4 show that the explanatory power in equation (4) has improved. Therefore, the model in Table 4 is preferred. From the findings, it is interesting to note that the estimated explanatory variables (i.e., $P G D P$ and $P$ ) in equation (4) become insignificant when Japanese FDI is included in equation (7). On the other hand, the estimated coefficient of Japanese FDI is found to be significant in predicting the demand of Japanese manufacturing affiliates' goods in 
China (equation (6)). Therefore, we strongly believe that Japanese FDI could have act as a mediator in predicting their sales in China. According to Baron and Kenny (1986), before making inferences from the model regarding its mediating effects, the estimated coefficients in equation (4), equation (5) and equation (6) must be significant. Based on Table 2, full mediation is established when the mediator (FDI) is significant in equation (7) and the previously significant estimated coefficient of explanatory variable (i.e., PGDPC and $P$ ) in equation (4) are insignificant in equation (7). The significance test for the indirect effects of the explanatory variable on dependent variable based on Baron and Kenny (1986) is reported in Table 4. Hence, Japanese FDI is found to be a full mediator between China's real gross domestic products per capita (PGDPC) and the sale of Japanese manufacturing affiliates in China, and between relative prices and Japanese manufacturing affiliates sales in China. From the findings, the estimated income elasticity of demand is found to be elastic (1.1042) and the estimated price elasticity of demand is found to be inelastic (-0.2284). The estimated coefficient of FDI (0.7639) shows that FDI will increase the sales of Japanese manufacturing in China significantly. This implies that Japanese FDI has successfully penetrated the market of China through FDI and there is an indirect effect between the macroeconomic variables and exports.

Table 3 Results for Model 1 (equation (1)) with GDP per capita for both trading partner

\begin{tabular}{|c|c|c|c|c|}
\hline Independent variables & Equation (4) & Equation (5) & Equation (6) & Equation (7) \\
\hline \multirow[t]{3}{*}{$C$} & & & $4.1590 * * *$ & \\
\hline & & & [0.7989] & \\
\hline & & & $(5.206)$ & \\
\hline \multirow[t]{3}{*}{$P G D P C$} & $1.1596^{* * *}$ & $1.4590 * * *$ & & 0.2320 \\
\hline & {$[0.2163]$} & {$[0.1865]$} & & {$[0.2502]$} \\
\hline & $(5.362)$ & $(7.821)$ & & $(0.927)$ \\
\hline \multirow[t]{3}{*}{$P G D P J$} & 0.7869 & 0.3488 & & 0.5652 \\
\hline & {$[0.6559]$} & {$[0.5658]$} & & {$[0.5540]$} \\
\hline & $(1.200)$ & $(0.616)$ & & $(1.020)$ \\
\hline \multirow[t]{3}{*}{$P$} & $-3.1121 * * *$ & $-2.9275 * * *$ & & -1.2510 \\
\hline & {$[1.1258]$} & {$[0.9711]$} & & {$[1.0089]$} \\
\hline & $(-2.764)$ & $(-3.015)$ & & $(-1.240)$ \\
\hline \multirow[t]{3}{*}{$F D I$} & & & $0.7639 * * *$ & $0.6357 * * *$ \\
\hline & & & {$[0.07826]$} & {$[0.1176]$} \\
\hline & & & $(9.761)$ & $(5.408)$ \\
\hline$R^{2}$ & 0.3998 & 0.7025 & 0.7834 & 0.7943 \\
\hline Adjusted- $R^{2}$ & 0.3762 & 0.6594 & 0.7589 & 0.7611 \\
\hline LM test & 61.91 & 47.32 & 93.30 & 48.77 \\
\hline Hausman test & 2.49 & 11.07 & 0.29 & 1.62 \\
\hline Model & Fixed effect & Fixed effect & Random effect & Fixed effect \\
\hline
\end{tabular}

Notes: *** denotes statistically significant at 1\%; Standard error is provided in [ ]; $t$-statistics is provided in ( ) for fixed effect panel model; $z$-statistic is provided in ( ) for random effect panel model. 
Table 4 Results for Model 1 (equation (1))

\begin{tabular}{|c|c|c|c|c|c|}
\hline Independent variables & Equation (4) & Equation (5) & Equation (6) & Equation (7) & $\begin{array}{l}\text { Baron and Kenny } \\
\text { (1986) estimation }\end{array}$ \\
\hline \multirow[t]{3}{*}{$C$} & & & $4.1590 * * *$ & & \\
\hline & & & [0.7989] & & \\
\hline & & & (5.206) & & \\
\hline \multirow[t]{3}{*}{$P G D P C$} & $1.1381 * * *$ & $1.4455^{* * *}$ & & 0.205 & $1.1042 * * *$ \\
\hline & {$[0.2174]$} & {$[0.1863]$} & & [0.2489] & {$[0.1824]$} \\
\hline & $(5.234)$ & $(7.761)$ & & $(0.824)$ & $(6.0531)$ \\
\hline \multirow[t]{3}{*}{$P$} & $-0.2284 * * *$ & $-0.2033^{* * *}$ & & -0.0971 & $-0.1553^{* * *}$ \\
\hline & {$[0.0733]$} & {$[0.0628]$} & & {$[0.0659]$} & {$[0.0508]$} \\
\hline & $(-3.114)$ & $(-3.237)$ & & $(-1.472)$ & $(-3.058)$ \\
\hline \multirow[t]{3}{*}{ FDI } & & & $0.7639 * * *$ & $0.6455^{* * *}$ & \\
\hline & & & {$[0.0784]$} & {$[0.1171]$} & \\
\hline & & & $(9.761)$ & $(5.512)$ & \\
\hline$R^{2}$ & 0.6992 & 0.6999 & 0.7834 & 0.7911 & \\
\hline Adjusted- $R^{2}$ & 0.6605 & 0.6614 & 0.7589 & 0.7609 & \\
\hline LM test & 86.76 & 67.64 & 93.30 & 51.71 & \\
\hline Hausman test & 1.35 & 9.04 & 0.29 & 3.03 & \\
\hline Model & Fixed effect & Fixed effect & Random effect & Fixed effect & \\
\hline \multicolumn{6}{|c|}{$\begin{array}{l}\text { Notes: *** denotes statistically significant at 1\%; Standard error is provided in [ ]; } t \text {-statistics is provided in ( ) for fixed effe } \\
\text { panel model; } z \text {-statistic is provided in ( ) for random effect panel model and Barron and Kenny (1986) test statistic. }\end{array}$} \\
\hline Tab & ble 5 Results for & Iodel 2 (equation & with GDP per cap & for both tradin & tner \\
\hline $\begin{array}{l}\text { Independent } \\
\text { variables }\end{array}$ & Equation (4) & Equation (5) & Equation (6) & Equation (7) & $\begin{array}{l}\text { Baron and Kenny } \\
(1986) \text { estimation }\end{array}$ \\
\hline \multirow[t]{3}{*}{ PGDPC } & $1.4169 * * *$ & $1.4590 * * *$ & & $0.8038 * * *$ & $0.5872 * * *$ \\
\hline & {$[0.1580]$} & {$[0.1865]$} & & {$[0.1898]$} & {$[0.1497]$} \\
\hline & $(8.969)$ & $(7.821)$ & & $(4.235)$ & $(3.923)$ \\
\hline \multirow[t]{3}{*}{$P G D P J$} & 0.1644 & 0.3488 & & 0.178 & 0.0169 \\
\hline & {$[0.4791]$} & {$[0.5658]$} & & [0.4202] & [0.3086] \\
\hline & $(0.343)$ & $(0.616)$ & & $(0.042)$ & $(0.055)$ \\
\hline \multirow[t]{3}{*}{$P$} & $-3.3239 * * *$ & $-2.9275 * * *$ & & $-2.0938^{* * *}$ & $-1.5295 * * *$ \\
\hline & [0.8224] & [0.9711] & & {$[0.7652]$} & {$[0.5794]$} \\
\hline & $(-4.042$ & $(-3.015)$ & & $(-2.736)$ & $(2.640)$ \\
\hline \multirow[t]{3}{*}{$F D I$} & & & $0.7305^{* * *}$ & $0.4202 * * *$ & \\
\hline & & & [0.0684] & [0.0892] & \\
\hline & & & $(10.684)$ & $(4.713)$ & \\
\hline$R^{2}$ & 0.9005 & 0.7025 & 0.8998 & 0.925 & \\
\hline Adjusted- $R^{2}$ & 0.8861 & 0.6594 & 0.8855 & 0.9129 & \\
\hline LM test & 189.20 & 47.32 & 225.77 & 160.21 & \\
\hline Hausman test & 5.25 & 11.07 & 0.80 & 5.24 & \\
\hline Model & Fixed effect & Fixed effect & Fixed effect & Fixed effect & \\
\hline
\end{tabular}

Notes: $* * *$ denotes statistically significant at $1 \%$; Standard error is provided in [ ]; $t$-statistics is provided in ( ) for fixed effect panel model; z-statistic is provided in ( ) for Barron and Kenny (1986) test statistic. 
In order to examine whether Japanese FDI in China is hollowing out the domestic firms in Japan, Model 2 (equation (2)) is estimated. The results are shown in Table 5 and Table 6. The results in Table 5 is preferred as all estimated equations have relatively high explanatory power and correct signs for the estimated coefficient when $P G D P J$ is included in the estimation. The authors found that Japanese real domestic product contributes insignificantly to FDI inflow in China. The findings of the study are consistent with YU and ZHAO (2008) who found that Japanese FDI in China will increase the China's exports to Japan. This study also supports previous studies citing a positive relationship between FDI and exports in China (Dritsaki, et al., 2004; LIU, et al., 2001; SUN, 2001; ZHANG \& Felmingham, 2001; ZHANG \& SONG, 2000). In accordance with the criteria recommended by Baron and Kenny (1986) in Table 2, Japanese FDI is found to be a partial mediator in promoting bilateral China-Japan exports flow. It is interesting to note that the estimated price elasticity of demand which takes into account of the impact of exchange rate, wage and capital differentials between China and Japan, is elastic (-1.5295). This implies that depreciation in Chinese RMB will increase the exports of Japanese manufacturing affiliates in China to Japan which in turn hurt the domestic firms in Japan.

Table 6 Results for Model 2 (equation (2))

\begin{tabular}{lcccc}
\hline Independent variables & Equation (4) & Equation (5) & Equation (6) & Equation (7) \\
\hline PGDPJ & -0.0685 & 0.1122 & & -0.1444 \\
& {$[0.06983]$} & {$[0.7703]$} & & {$[0.4678]$} \\
& $(-0.098)$ & $(0.146)$ & & $-0.309)$ \\
$P$ & $-0.3037^{* * *}$ & $-0.2795^{* * *}$ & $-0.1145^{* * *}$ \\
& {$[0.0791]$} & {$[0.0873]$} & {$[0.0567]$} \\
FDI & $(-3.841)$ & $(-3.204)$ & & $(-2.019)$ \\
& & & $0.7305^{* * *}$ & $0.6770^{* * *}$ \\
& & {$[0.0684]$} & {$[0.0726]$} \\
$R^{2}$ & & $(10.684)$ & $(9.328)$ \\
Adjusted- $R^{2}$ & 0.7861 & 0.4419 & 0.8998 & 0.7911 \\
LM test & 0.7586 & 0.3702 & 0.8855 & 0.7609 \\
Hausman test & 145.16 & 21.07 & 225.77 & 179.89 \\
Model & 5.67 & 4.56 & 0.80 & 4.28 \\
\hline
\end{tabular}

Notes: $* * *$ denotes statistically significant at $1 \%$; Standard error is provided in [ ]; $t$-statistic is provided in ( ).

The authors further this analysis to examine Japan's strategy in penetrating the market of other countries through FDI in China. Model 3 (equation (3)) is estimated and the results are summarized in Table 7 and Table 8. We found that Japanese FDI is not a mediator for Japanese MNEs in China to penetrate the market of other countries, but the estimated coefficient of FDI is a significant positive value $(0.7305)$ based on the bivariate FDI-exports model in equation (6). Furthermore, the estimated coefficients for relative price, China's and the world's real domestic products per capita have the expected signs and significance in equation (4), equation (5) and equation (7), except PGDPW in equation (5). This implies that Japan could have established a strong network (e.g., economic, political and social relationships) with other countries that encourage Japan to set up their production bases in China to gain the benefits of comparative advantage of China and to avoid trade barriers. Therefore, the network effect is important in international trade analysis (Greaney, 2009; Greaney, 2005; Greaney, 2003; Casella \& Rauch, 2002; Spencer \& Qiu, 2001; McLaren, 1999; Rauch, 1996). The findings also show that the depreciation of RMB will increase the Japanese manufacturing affiliates in China to other countries. 
Table 7 Results for Model 3 (equation (3)) with GDP per capita for both trading partner

\begin{tabular}{|c|c|c|c|c|}
\hline Independent variables & Equation (4) & Equation (5) & Equation (6) & Equation (7) \\
\hline \multirow[t]{3}{*}{$C$} & & $14.13867 * * *$ & & \\
\hline & & {$[4.2301]$} & & \\
\hline & & $(3.342)$ & & \\
\hline \multirow[t]{3}{*}{ PGDPW } & $2.7118^{* *}$ & -0.2010 & & $2.7116 * *$ \\
\hline & [1.1342] & {$[0.4708]$} & & [1.1425] \\
\hline & $(2.391)$ & $(-0.427)$ & & $(2.373)$ \\
\hline \multirow[t]{3}{*}{$P G D P C$} & $0.7426^{* * *}$ & $0.4792 * *$ & & $0.7409 * *$ \\
\hline & {$[0.2699]$} & {$[0.2176]$} & & {$[0.2804]$} \\
\hline & $(2.751)$ & $(2.202)$ & & $(2.642)$ \\
\hline \multirow[t]{3}{*}{$P$} & $-2.1939 * * *$ & $-2.2769 * * *$ & & $-2.1872 * * *$ \\
\hline & {$[0.4351]$} & {$[0.3701]$} & & {$[0.5198]$} \\
\hline & $(-5.042)$ & $(-6.153)$ & & $(-4.207)$ \\
\hline \multirow[t]{3}{*}{ FDI } & & & $0.7312 * * *$ & 0.0031 \\
\hline & & & {$[0.1059]$} & {$[0.1279]$} \\
\hline & & & $(6.973)$ & $(0.024)$ \\
\hline$R^{2}$ & 0.9312 & 0.7551 & 0.8724 & 0.9312 \\
\hline Adjusted- $R^{2}$ & 0.9212 & 0.7196 & 0.8580 & 0.9200 \\
\hline LM Test & 264.01 & 101.17 & 160.77 & 103.51 \\
\hline Hausman Test & 5.93 & 0.27 & 3.51 & 15.47 \\
\hline Model & Fixed effect & Random effect & Fixed effect & Fixed effect \\
\hline
\end{tabular}

Notes: ${ }^{* * *}$ and ${ }^{* *}$ denote statistically significant at $1 \%$ and $5 \%$ respectively; Standard error is provided in [ ]; $t$-statistic is provided in ( ) for fixed effect panel model; $z$ - statistic is provided in ( ) for random effect panel model.

Table 8 Results for Model 3 (equation (3))

\begin{tabular}{|c|c|c|c|c|}
\hline Independent variables & Equation (4) & Equation (5) & Equation (6) & Equation (7) \\
\hline \multirow[t]{3}{*}{$C$} & & $14.5302 * * *$ & & \\
\hline & & {$[4.3578]$} & & \\
\hline & & $(3.334)$ & & \\
\hline \multirow[t]{3}{*}{ PGDPW } & $3.2158^{* * *}$ & 0.18165 & & $3.1790 * * *$ \\
\hline & {$[1.1706]$} & {$[0.4514]$} & & {$[1.1766]$} \\
\hline & $(2.747)$ & $(0.6874)$ & & $(2.702)$ \\
\hline \multirow[t]{3}{*}{$P$} & $-3.0661 * * *$ & $-2.8248 * * *$ & & $-2.8245 * * *$ \\
\hline & {$[0.3117]$} & {$[0.2805]$} & & {$[0.4800]$} \\
\hline & $(-9.838)$ & $(-10.069)$ & & $(-5.884)$ \\
\hline \multirow[t]{3}{*}{ FDI } & & & $0.7312 * * *$ & 0.0858 \\
\hline & & & {$[0.1059]$} & [0.1293] \\
\hline & & & $(6.973)$ & $(0.664)$ \\
\hline$R^{2}$ & 0.9236 & 0.7395 & 0.8724 & 0.9241 \\
\hline Adjusted- $R^{2}$ & 0.9138 & 0.7060 & 0.8580 & 0.9131 \\
\hline LM test & 283.20 & 103.64 & 160.77 & 117.24 \\
\hline Hausman test & 5.58 & 0.40 & 3.51 & 14.36 \\
\hline Model & Fixed effect & Random effect & Fixed effect & Fixed effect \\
\hline
\end{tabular}

Notes: *** denotes statistically significant at 1\%; Standard error is provided in [ ]; $t$-statistic is provided in ( ) for fixed effect panel model; $z$ - statistic is provided in ( ) for random effect panel model.

Overall, the authors noted that the estimated coefficients of Japanese manufacturing affiliates in China with significant values are inelastic in all models. This shows that Japanese FDI in China is market-seeking and 
efficiency-seeking where efficiency-seeking is dominating the market-seeking effects. The depreciation of RMB will hurt the domestic firms in Japan, but increase the exports of Japanese manufacturing affiliates in China to other countries. Some insights are drawn from this study to provide suggestions to form a win-win platform for both Japan and China as follows: (1) depreciation of RMB could increase the exports of Japanese manufacturing affiliates in China to Japan and other countries as well as increase the sales of Japanese manufacturing affiliates in China; (2) increase import tariffs of Japan may safeguard the domestic firms; (3) China continues to appear to have comparative advantage in labor-intensive product or for assembly trades; (4) China should provide incentives to attract Japanese FDI for domestic development as Japan has also invested heavily in India and ASEAN countries in 2007 (JETRO). The implementation of the above insights, some of which are contradictory in effects, need to be balanced in nature.

\section{Conclusions}

In conclusion, this study contributes to both conceptual and empirical evidence to examine the mediating role of export-oriented Japanese FDI in China. The empirical results indicate that there are indirect relationships between the macroeconomic variables and exports. Japan and China are vertically integrated as the significant estimated coefficient of Japanese FDI is positive and inelastic. Japanese FDI in China is found to be a full mediator to increase the sales of Japanese manufacturing affiliates in China. This indicates that Japanese FDI act as main conduits for Japan to penetrate the market of China. The results show that Japanese FDI in China increases the sales of Japanese manufacturing affiliates in China and their exports to other countries. Japanese FDI in China exhibits both market-seeking and efficiency seeking purposes where efficiency seeking effects dominates market-seeking effects. From the insights and conclusions above, the eventual migration of the labor intensive assembly sectors of manufacturing is a real possibility within the next decade as China continues in defending a lower valuation of the RMB and maintaining a low labor cost structure arising from the large labor pool. Japanese multinationals, on the other hand, will have to move up in the value chain within Japan rather than resisting the erosion of price efficiencies.

As network effects could have led to Japanese FDI in China, the mediating role of trade flows remains to be examined in future research study. Additionally, disaggregated analysis at sectoral levels may yield more important insights and this remains an area for future research work.

\section{References:}

Apergis, N., Lyroudi, K. \& Vamvakidis, A.. (2008). The relationship between foreign direct investment and economic growth: Evidence from transition countries. Transition Studies Review, 15, 37-51.

Baron, R. M. \& Kenny, D. A.. (1986). The moderator-mediator variable distinction in social psychological research: Conceptual, strategic and statistical considerations. Journal of Personality and Social Psychology, 51, 1173-1182.

Blonigen, B. A.. (2005). A review of the empirical literature on FDI determinants. Atlantic Economic Journal, 33, $383-403$.

Branstetter, L.. (2006). Is foreign direct investment a channel of knowledge spillovers? Evidence from Japan's FDI in the United States. Journal of International Economics, 68, 325-344.

Camarero, M. \& Tamarit, C.. (2004). Estimating the export and import demand for manufactured goods: The role of FDI. Review of World Economics, 140, 347-375.

Casella, A. \& Rauch, J. E.. (2002). Anonymous market and group ties in international trade. Journal of International Economics, 58, $19-47$.

Cassidy, J. F. \& Callaghan, B. A.. (2006). Spatial determinants of Japanese FDI in China. Japan and the World Economy, 18, 512-527.

CHEN, R. \& WANG, J.. (2007). Panel data analyses on FDI and China's Exports: 1995-2002. Data Science Journal, 6, S364-S373.

Dritsaki, M., Dritsaki, C. \& Adamopoulos, A.. (2004). A causal relationship between trade, foreign investment and economic growth for Greece. American Journal of Applied Sciences, 1, 230-235. 
Edwards, J. R. \& Lambert, L. S.. (2007). Methods for integrating moderation and mediation: A general analytical framework using moderated path analysis. Psychological Method, 12, 1-22.

Greaney, T. M.. (2003). Reverse importing and asymmetric trade and FDI: A networks explanation. Journal of International Economics, 61, 453-465.

Greaney, T. M.. (2005). Measuring network effects on trade: Are Japanese affiliates distinctive? Journal of the Japanese and International Economies, 19, 194-214.

Greaney, T. M.. (2009). Measuring network effects on trade: A reexamination. Japan and the World Economy, 21, $219-225$.

Hair, J. F. Jr., Black, W. C., Babin, B. J., Anderson, R. E. \& Tatham, R. L.. (2006). Multivariate data analysis (6th ed.). New Jersey: Pearson Education Inc.

Helpman, E.. (1984). A simple theory of international trade with multinational corporations. The Journal of Political Economy, 92, 451-471.

Hermes, N. \& Lensink, R.. (2003). Foreign direct investment, financial development and economic growth. Journal of Development Studies, 40, 142-163.

Holmbeck, G. N.. (1997). Toward terminological, conceptual, and statistical clarity in the study of mediators and moderators: Examples from the child-clinical and pediatric psychology literatures. Journal of Consulting and Clinical Psychology, 65, 599-610.

KANG, S. J. \& Lee, H. S.. (2007). The determinants of location choice of South Korean FDI in China. Japan and the World Economy, $19,441-460$.

Kenny, D. A., Kashy, D. A. \& Bolger, N.. (1998). Data analysis in social psychology. In: Gilbert, D. T., Fiske, S. T. \& Lindzey, G. (Eds.), The handbook of social psychology. New York: Oxford University Press, 233-265.

Kiyota, K. \& Urata, S.. (2008). The role of multinational firms in international trade: The case of Japan. Japan and the World Economy, 20, 338-352.

Kumar, S.. (2009). An empirical evaluation of export demand in China. Journal of Chinese Economic and Foreign Trade Studies, 2 , 100-109.

LIU, X., WANG, C. \& WEI, Y.. (2001). Causal links between foreign direct investment and trade in China. China Economic Review, $12,190-202$.

Mackinnon, D. P., Krull, J. L. \& Lockwood, C. M.. (2000). Equivalence of the mediation, confounding, and suppression effect. Prevention Science, 1, 173-181.

Mackinnon, D. P., Lockwood, C. M., Hoffman, J. M., West, S. G. \& Sheets, V.. (2002). A comparison of methods to test mediation and other intervening variables effects. Psychological Methods, 7, 83-104.

Markusen, J. R.. (1983). Factor movements and commodity trade as complements. Journal of International Economics, 14, 341-356.

Markusen, J. R.. (1984). Multinationals, multi-plant economies and the gains from trade. Journal of International Economics, 16, 205-226.

McLaren, J.. (1999). Supplier relations and the market context: A theory of handshakes. Journal of International Economics, 48, 121-138.

Mundell, R. A.. (1957). International trade and factor mobility. American Economic Review, 47, 321-335.

Rauch, J. E.. (1996). Trade and search: Social capital, sogo shosha, and spillovers. NBER working paper No. W5618. Retrieved from http://ssrn.com/abstract=4238.

Ryu, E., West, S. G. \& Sousa, K. H.. (2009). Mediation and moderation: Testing relationships between symptom status, functional health, and quality of life in HIV patients. Multivariate Behavioral Research, 44, 213-232.

Spencer, B. J. \& Qiu, L. D.. (2001). Keiretsu and relationship-specific investment: A barrier to trade? International Economic Review, 42, 871-901.

SUN, H.. (2001). Foreign direct investment and regional export performance in China. Journal of Regional Science, 41, 317-336.

SUN, Q., TONG, W. \& YU, Q.. (2002). Determinants of foreign direct investment across China. Journal of International Money and Finance, 21, 79-113.

Swenson, D. L.. (2004). Foreign investment and the mediation of trade flows. Review of International Economics, 12, 609-629.

Vukšić, G.. (2005). Impact of foreign direct investment on Croatian manufacturing exports. Financial Theory and Practice, 29, 131-158.

WANG, S., TONG, T.W., CHEN, G. \& Kim, H.. (2009). Expatriate utilization and foreign direct performance: The mediating role of knowledge transfer. Journal of Management, 35, 1181-1206.

WONG, K. N. \& TANG, T. C.. (2009). New evidence on the causal linkages between foreign direct investment, exports and imports in Malaysia. The Icfai Journal of Applied Economics, 8, 20-25.

XING, Y. \& ZHAO, L.. (2008). Reverse imports, foreign direct investment and exchange rates. Japan and the World Economy, 20, 275-289.

YU, J. \& ZHAO, W.. (2008). The impacts of Japanese direct investment in China on the Sino-Japanese bilateral trade. Journal of Chinese Economic and Foreign Trade Studies, 1, 185-199.

ZHANG, Q. \& Felmingham, B.. (2001). The relationship between inward direct foreign investment and China's provincial export trade. China Economic Review, 12, 82-99.

ZHANG, K. H. \& SONG, S.. (2000). Promoting exports: The role of inward FDI in China. China Economic Review, 11, 385-396.

(Edited by Ruby and Chris) 